\begin{tabular}{|c|c|c|}
\hline \multirow[t]{2}{*}{7} & $\begin{array}{l}\text { International Journal of Current Research in } \\
\text { Biosciences and Plant Biology }\end{array}$ & \\
\hline & Volume $4 \bullet$ Number 6 (June-2017)•ISSN: 2349-8080 (Online) & \\
\hline PUBLISHERS & Journal homepage: www.ijcrbp.com & \\
\hline
\end{tabular}

\title{
Preliminary Phytochemical Analysis and Antibacterial Activity of Leaf Extracts of Capparis sepiaria, Euphorbia heterophylla and Tamilnadia uliginosa
}

\author{
B. Kalpana ${ }^{1}$ and M. Prakash ${ }^{2} *$ \\ ${ }^{1}$ Research \& Development Centre, Bharathiar University, Coimbatore-641 046, Tamil Nadu, India \\ ${ }^{2}$ Department of Microbiology, Kanchi Shri Krishna College of Arts and Science, Kilambi, Kancheepuram-631 551, Tamil Nadu, \\ India
}

*Corresponding author.

\begin{abstract}
In the present study the ethanol and petroleum ether extracts of Capparis sepiaria, Euphorbia heterophylla and Tamilnadia uliginosa leaves were subjected to preliminary phytochemical analysis and tested for antibacterial activity using resazurin dye reduction test. The minimum inhibitory concentration (MIC) of the ethanolic and petroleum ether extracts of the leaves were rapidly assessed against five different bacterial species, viz., Micrococcus luteus (NCIM-2103), Staphylococcus epidermidis (NCIM-2493), Escherichia coli (NCIM-2065), Pseudomonas cepacia (NCIM-2106) and Bacillus megaterium (NCIM-2187). The highest antibacterial activity with least MIC values were recorded in the ethanolic leaf extracts of Tamilnadia uliginosa against the test bacteria $(\mathrm{MIC}=62.5-250 \mu \mathrm{L})$. In petroleum ether extracts of all the plants tested, Tamilnadia uliginosa recorded enumerable activity with least MIC value ranging between $125-500 \mu \mathrm{L}$. The results indicate extracts of Tamilnadia uliginosa leaves has good antimicrobial activity in crude form.
\end{abstract}

\section{Article Info}

Accepted: 22 April 2017

Available Online: 06 June 2017

\section{Keywords}

Antibacterial activity

Leaf extract

Medicinal plants

Minimum inhibitory concentration

Phytochemicals

Resazurin reduction test

\section{Introduction}

In the recent days approximately $20 \%$ of the plants found in the world have been submitted to pharmacological or biological test, and substantial numbers of new antibiotics introduced on the market are obtained from natural or semisynthetic resources (Ogu and Agu, 1995). The every part of the medicinal plant such as root, bark, leaf, etc. is containing medicinal properties based up on the presence of chemical constituents. The chemical constitutes contributes to the protective effect against bacterial, fungal and viral (Okwu, 2005).

In the recent years, research on medicinal plants has attracted a lot of attentions globally. Large body of evidence has accumulated to demonstrate the promising potential of Medicinal Plants used in various traditional, complementary and alternate systems of treatment of human diseases. Plants are rich in a wide variety of secondary metabolites such as tannins terpenoids, alkaloids, flavonoids, etc, which have been found in 
vitro to have antimicrobial properties (Dahanukar et al., 2000).

Majority of the studies concerned with the antimicrobial activities of plant extracts have been performed using disc diffusion or well diffusion method. However, there are rapid procedures developed to screen plant extracts for assaying antibacterial activity. A new high throughput antibacterial method employing the dye resazurin as an indicator of bacterial growth was developed to evaluate drug susceptibility by combined measurements of microtitre-plates, colorimetric and haemocytometric assays. The bacterial strains Escherichia coli, Bacillus subtilis, Pseudomonas aeruginosa and Staphylococcus aureus (multi-drug resistant strain) were used to evaluate the preliminary screening of plant extracts, minimum inhibition concentration (MIC) and minimum bacterial concentration (MBC) with streptomycin and tetracycline as reference antibiotics (Karuppusamy and Rajasekaran, 2009).

In the present study, antibacterial activities of the ethanolic and petroleum ether extracts of Capparis sepiaria, Euphorbia heterophylla and Tamilnadia uliginosa leaf extracts against selected bacterial species, Micrococcus luteus, Staphylococcus epidermidis, Escherichia coli, Pseudomonas cepacia and Bacillus megaterium.

\section{Materials and methods}

\section{Collection of leaves}

The leaves of the medicinal plants selected for the present study were collected from Sirumalai hills (Eastern Ghats), Dindigul, Tamil Nadu and the identification was confirmed using standard local floras (Gamble and Fischer, 1957; Matthews, 1983). The names of the plants identified were Capparis sepiaria $\mathrm{L}$. (Capparaceae), Euphorbia heterophylla L. (Euphorbiaceae) and Tamilnadia uliginosa (Retz.) Tirveng. \& Sastre (Family: Rubiaceae). The leaves collected were shade dried and powdered using mortar and pastle. A fine powder obtained was stored in air tight poly bags and used for preparation of extract.

\section{Preparation of extract}

The cold extraction procedure was used for extracting leaves with solvents as per the procedure adopted by
Prakash and Karmegam (2012) and Vigneshwari et al. (2014). The leaves collected were transported to the laboratory for further processing. The leaves of the plants collected were individually washed with tap water, blotted with filter paper and spread over news paper for air drying under shade. After complete dryness, the leaves of individual plants were powdered using a mixer grinder. A known quantity of leaf powder $(100 \mathrm{~g})$ of each plant leaves was taken in a 250 $\mathrm{ml}$ conical flask and added with 100-200 ml of ethanol individually. The solvent-leaf powder mixtures were kept at room temperature for $48 \mathrm{hrs}$ and rapidly stirred using glass rod every $8 \mathrm{hrs}$. After $48 \mathrm{hrs}$, the extract of each plant was filtered through Whatmann No.1 filter paper to exclude the leaf powder. Then each filtrate was kept in beaker on a water bath at $45^{\circ} \mathrm{C}$ until the solvent gets evaporated. A greasy final material (crude extract) obtained for each plant was transferred to screw cap tubes and stored under refrigerated condition till use.

\section{Preliminary phytochemical analysis}

Chemical tests were carried out on the solvent extracts for the qualitative determination of phytochemical constituents as described by Harborne (1973), Trease and Evans (1989) and Sofowora (1993).

\section{Test for alkaloids}

The extract $(0.5 \mathrm{~g})$ was diluted to $10 \mathrm{ml}$ with acid alcohol, boiled and filtered. To $5 \mathrm{ml}$ of the filtrate, $2 \mathrm{ml}$ of dilute ammonia was added. $5 \mathrm{ml}$ of chloroform was added and shaken gently to extract the alkaloidal base. The chloroform layer was extracted with $10 \mathrm{ml}$ of acetic acid. This was divided into two portions. Mayer's reagent was added to one portion and Draggendorff's reagent to the other. The formation of a cream (with Mayer's reagent) or reddish brown precipitate (with Draggendorff's reagent) was regarded as positive for the presence of alkaloids.

\section{Test for flavonoids}

Three methods were used to test for flavonoids. First, dilute ammonia $(5 \mathrm{ml})$ was added to a portion of an aqueous filtrate of the extract. Concentrated sulphuric acid $(1 \mathrm{ml})$ was added. A yellow colouration that disappears on standing indicates the presence of flavonoids. Second, a few drops of $1 \%$ aluminium solution were added to a portion of the filtrate. A yellow 
colouration indicates the presence of flavonoids. Third, a portion of the extract was heated with $10 \mathrm{ml}$ of ethyl acetate over a steam bath for $3 \mathrm{~min}$. The mixture was filtered and $4 \mathrm{ml}$ of the filtrate was shaken with $1 \mathrm{ml}$ of dilute ammonia solution. A yellow colouration indicates the presence of flavonoids.

\section{Test for phenols}

(i) $0.5 \mathrm{ml}$ of extract was added $1 \mathrm{ml}$ of $5 \%$ of ferric chloride was added and observed deep blue colour was developed.

(ii) To $0.5 \mathrm{ml}$ of extract, $2 \mathrm{ml}$ of $10 \%$ acetic acid was added in a test tube and allowed to few seconds and observed white precipitation.

\section{Test for terpenoids (Salkowski test)}

To $0.5 \mathrm{ml}$ each of the extracts, $2 \mathrm{ml}$ of chloroform was added. Concentrated $\mathrm{H}_{2} \mathrm{SO}_{4}(3 \mathrm{ml})$ was carefully added to form a layer. A reddish brown colouration of the interface indicates the presence of terpenoids.

\section{Test for saponins}

To $0.5 \mathrm{ml}$ of extract was added $5 \mathrm{ml}$ of distilled water in a test tube. The solution was shaken vigourously and observed for a stable persistent froth. The frothing was mixed with 3 drops of olive oil and shaken vigourously after which it was observed for the formation of an emulsion.

\section{Tests for steroids}

(i) A red colour produced in the lower chloroform layer when $2 \mathrm{ml}$ of organic extract was dissolved in $2 \mathrm{ml}$ of chloroform and $2 \mathrm{ml}$ concentrated sulphuric acid added indicates the presence of steroids.

(ii) The development of a greenish colour when $2 \mathrm{ml}$ of the organic extract was dissolved in $2 \mathrm{ml}$ of chloroform and treated with sulphuric and acetic acids indicates the presence of steroids.

\section{Test for tannins}

The extract $(0.5 \mathrm{ml})$ was boiled in $10 \mathrm{ml}$ of water in a test tube and then filtered. A few drops of $0.1 \%$ ferric chloride was added and observed for brownish green or a blue-black colouration.

\section{Test for amino acids}

The extract $(0.5 \mathrm{ml})$ was added to $5 \mathrm{ml}$ of phenol Folin's reagent in a test tube and heated in boiling water bath for $30 \mathrm{~min}$ and incubated in dark room for $15 \mathrm{~min}$. The blue colour development indicates presence of amino acids.

\section{Tests for carbohydrates (Molisch's test)}

To $0.5 \mathrm{ml}$ of extract solution, $1 \mathrm{ml}$ of water and 5-8 drops of Fehling's solution was added at hot and observed for brick red precipitate.

\section{Antimicrobial activity by resazurin dye reduction test}

\section{Selection of microorganisms}

The selected bacterial strains are collected from NCIM (National centre for industrial microorganisms, Chandigarh). The following bacterial species are used for the study. Micrococcus luteus (NCIM-2103), Staphylococcus epidermidis (NCIM-2493), Escherichia coli (NCIM-2065), Pseudomonas cepacia (NCIM-2106) and Bacillus megaterium (NCIM-2187).

\section{Resazurin dye reduction method}

The antibacterial activity of plant extracts was determined by resazurin dye reduction method (Karuppusamy and Rajasekaran, 2009). The dye resazurin was obtained from Sigma chemicals and prepared as $10 \mathrm{~g} / 1$ sterile water stock solution, stored in frozen at $-20^{\circ} \mathrm{C}$, thawed and diluted $1: 10$ in sterile water when required.

\section{Titreplate resazurin assay}

The titreplate resazurin assay was performed in 96-well plates. Two-fold dilutions of each antibiotics and plant extracts were prepared in the test wells in complete nutrient broth, the final antibiotic concentrations being streptomycin $0.06 \mathrm{mg} / \mathrm{l}$ and tetracycline $0.12 \mathrm{mg} / \mathrm{l}$. Twenty microlitres of each bacterial suspension was added to $180 \mu \mathrm{l}$ of antibiotics and plant extracts containing culture medium. Control wells were prepared with culture medium and bacterial suspension only. The plates were sealed and incubated for $12 \mathrm{hr}$ at $37^{\circ} \mathrm{C}$. After each incubation time, $5 \mu 1$ of resazurin solution were added per well, colouring them blue. Plates were incubated at $37^{\circ} \mathrm{C}$ for additional $5 \mathrm{hr}$. After every one hour incubation time intervals plates were read for

B. Kalpana and M. Prakash (2017) / Preliminary Phytochemical Analysis and Antibacterial Activity of Leaf Extracts of Capparis sepiaria, 116 Euphorbia heterophylla and Tamilnadia uliginosa 
colour change from blue to pink and pink to colour less in live-bacterial strains containing wells. Extracts that showed preliminary microtitre-plate assay were reveled the fast decolouration of resazurin which extracts does not have possessed antibacterial potential. The bioactivity of the extracts were screened by which are all the extracts inhibit the dye reduction.

\section{Colorimetric resazurin assay}

Inoculums were prepared by various dilutions of $(1 \times 10 \mathrm{G}$ $-1 \times 10 G)$ growing bacterial strains in Mueller-Hinton broth in $10 \mathrm{ml}$ test tubes. The tubes were sealed and incubated under $37^{\circ} \mathrm{C}$ for $24 \mathrm{~h}$. After the incubation, test tubes were added various concentrations of the plant extracts prepared in the same broth ranges between 0.1 $\mathrm{mg} / \mathrm{l}$ to $10 \mathrm{mg} / \mathrm{l}$. Positive controls were prepared with only $9 \mathrm{ml}$ of broth containing $1 \mathrm{ml}$ of $0.1 \%$ resazurin solution without plant extracts and antibiotics. Antibiotic control tubes were also maintained aliquots of antibiotic solutions with respective bacterial strains in serial concentrations. In each test tubes added $1 \mathrm{ml}$ of $0.1 \%$ resazurin solution and the tubes were further incubated at $37^{\circ} \mathrm{C}$ for $5 \mathrm{~h}$. After the incubation, $1 \mathrm{ml}$ of solution were taken out form each test tube and read the absorbancy (OD) at $590 \mathrm{~nm}$ in a spectrophotometer for every one hour up to 5 hour. The minimum inhibition concentration (MIC) was defined as the lowest concentration of the extract that prevent colour change in the test tubes as OD is very close to positive control tube.

\section{Minimum inhibitory concentration}

The resazurin reduction test can be used for colorimetric determination of minimum inhibitory concentration (MIC) of the plant extracts on par with earlier method. After 5 hours of inoculation of sample extracts in different concentrations $(1000,500,250,125,62.5$, $31.25,15.62$ and $7.81 \mu \mathrm{L}$ ) with marker dye solution were taken the absorbancy of the cultured broth. The colour changes in the tubes can be markedly visible and also obtained MIC (maximum absorbancy) for potential antibacterial extracts showed the values close to the antibiotic control wells.

\section{Results and discussion}

\section{Preliminary phytochemical analysis}

The results of preliminary phytochemical analysis are given in Table 1. The ethanolic leaf extracts of Capparis sepiaria showed the presence of alkaloids, flavonoids, terpenoids, saponin, steroids and tannins, whereas, the ethanolic leaf extract of Tamilnadia uliginosa showed the presence of alkaloids, flavonoids, phenols, terpenoids, steroids and tannins. The petroleum ether leaf extracts showed the presence of alkaloids and steroids in common (Table 1). The ethanolic leaf extracts of Euphorbia heterophylla showed the presence of least number of phytochemical constituents such as alkaloids, flavonoids, terpenoids and saponin.

Table 1. Preliminary phytochemical analysis of ethanolic and petroleum ether extracts of selected plants.

\begin{tabular}{lccc}
\hline Phytochemicals & $\begin{array}{l}\text { Capparis } \\
\text { sepiaria }\end{array}$ & $\begin{array}{l}\text { Euphorbia } \\
\text { heterophylla }\end{array}$ & $\begin{array}{l}\text { Tamilnadia } \\
\text { uliginosa }\end{array}$ \\
\hline Ethanol extract & + & + & + \\
Alkaloids & + & + & + \\
Flavonoids & - & - & + \\
Phenols & + & + & + \\
Terpenoids & + & + & - \\
Saponin & + & - & + \\
Steroids & + & - & + \\
Tannins & + & + & + \\
Petroleum ether extract & + & + & - \\
Alkaloids & + & - & - \\
Flavonoids & + & - & + \\
Phenols & - & - & + \\
Terpenoids & - & + & - \\
Saponin & - & - & + \\
Steroids & + & - & + \\
Tannins & & + & + \\
\hline
\end{tabular}

(+) Presence of constituents; (-) Absence of constituents;

\section{Minimum inhibitory concentration}

The MIC values showed great variation among the extracts of Capparis sepiaria, Euphorbia heterophylla and Tamilnadia uliginosa as well as against the test bacteria (Tables 2 and 3 ).

The ethanolic leaf extracts of Capparis sepiaria showed least antibacterial activity which was 500-1000 $\mu \mathrm{L}$ except against Pseudomonas cepacia. Following this, Euphorbia heterophylla showed moderate activity against Bacillus megaterium, Escherichia coli and Micrococcus luteus and with low MIC against Pseudomonas cepacia and Staphylococcus epidermidis $(\mathrm{MIC}=125 \mu \mathrm{L})$. 
Table 2. Minimum Inhibitory Concentration (MIC) of ethanolic leaf extracts of medicinal plants against bacteria.

\begin{tabular}{|c|c|c|c|c|c|c|}
\hline \multirow[b]{2}{*}{ Sl. No. } & \multirow{2}{*}{$\begin{array}{l}\text { Ethanolic leaf extract } \\
\text { used }\end{array}$} & \multicolumn{5}{|l|}{ MIC $(\boldsymbol{\mu L})$} \\
\hline & & $\begin{array}{l}\text { Bacillus } \\
\text { megaterium }\end{array}$ & $\begin{array}{l}\text { Escherichia } \\
\text { coli }\end{array}$ & $\begin{array}{l}\text { Micrococcus } \\
\text { luteus }\end{array}$ & $\begin{array}{l}\text { Pseudomonas } \\
\text { cepacia }\end{array}$ & $\begin{array}{l}\text { Staphylococcus } \\
\text { epidermidis }\end{array}$ \\
\hline 1. & Capparis sepiaria & 1000 & 500 & 500 & 250 & 500 \\
\hline 2. & Euphorbia heterophylla & 500 & 250 & 250 & 125 & 125 \\
\hline 3. & Tamilnadia uliginosa & 250 & 125 & 62.5 & 62.5 & 62.5 \\
\hline
\end{tabular}

Table 3. Minimum Inhibitory Concentration (MIC) of petroleum ether leaf extracts of medicinal plants against bacteria.

\begin{tabular}{|c|c|c|c|c|c|c|}
\hline \multirow[b]{2}{*}{ Sl. No. } & \multirow[b]{2}{*}{$\begin{array}{l}\text { Petroleum ether leaf } \\
\text { extract used }\end{array}$} & \multicolumn{5}{|l|}{$\operatorname{MIC}(\mu \mathrm{L})$} \\
\hline & & $\begin{array}{l}\text { Bacillus } \\
\text { megaterium }\end{array}$ & $\begin{array}{l}\text { Escherichia } \\
\text { coli }\end{array}$ & $\begin{array}{l}\text { Micrococcus } \\
\text { luteus }\end{array}$ & $\begin{array}{l}\text { Pseudomonas } \\
\text { cepacia }\end{array}$ & $\begin{array}{l}\text { Staphylococcus } \\
\text { epidermidis }\end{array}$ \\
\hline 1. & Capparis sepiaria & 500 & 500 & 1000 & 250 & 500 \\
\hline 2. & Euphorbia heterophylla & 1000 & 1000 & 500 & 500 & 1000 \\
\hline 3. & Tamilnadia uliginosa & 250 & 250 & 125 & 250 & 500 \\
\hline
\end{tabular}

The highest antibacterial activity with least MIC values were recorded in the ethanolic leaf extracts of Tamilnadia uliginosa against the test bacteria (MIC = 62.5-250 $\mu \mathrm{L}$ ). In petroleum ether extracts of all the plants tested, Tamilnadia uliginosa recorded enumerable activity with least MIC value ranging between 125-500 $\mu \mathrm{L}$ (Table 3). Comparing the MIC values of ethanol and petroleum ether extracts of the leaves of same plant showed differences in activity (Figs. 1-3). Among the extracts of all the tested medicinal plants, ethanol extract showed pronounced antibacterial activity with least MIC values.

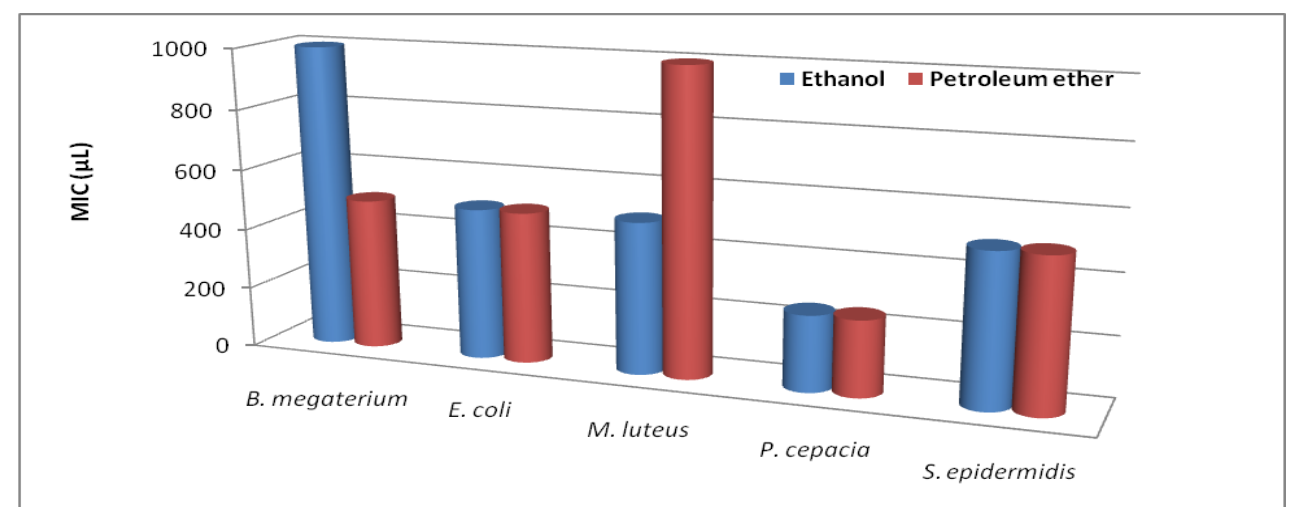

Fig. 1: Comparison of Minimum Inhibitory Concentration (MIC) of ethanolic and petroleum ether extracts of Capparis sepiaria leaves.

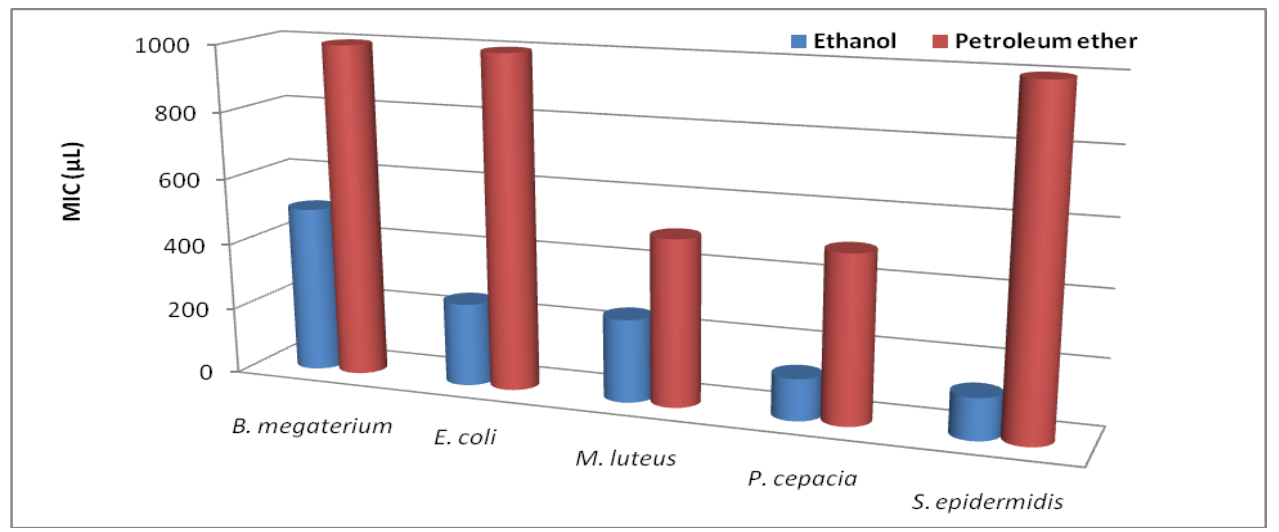

Fig. 2: Comparison of Minimum Inhibitory Concentration (MIC) of ethanolic and petroleum ether extracts of Euphorbia heterophylla leaves. 


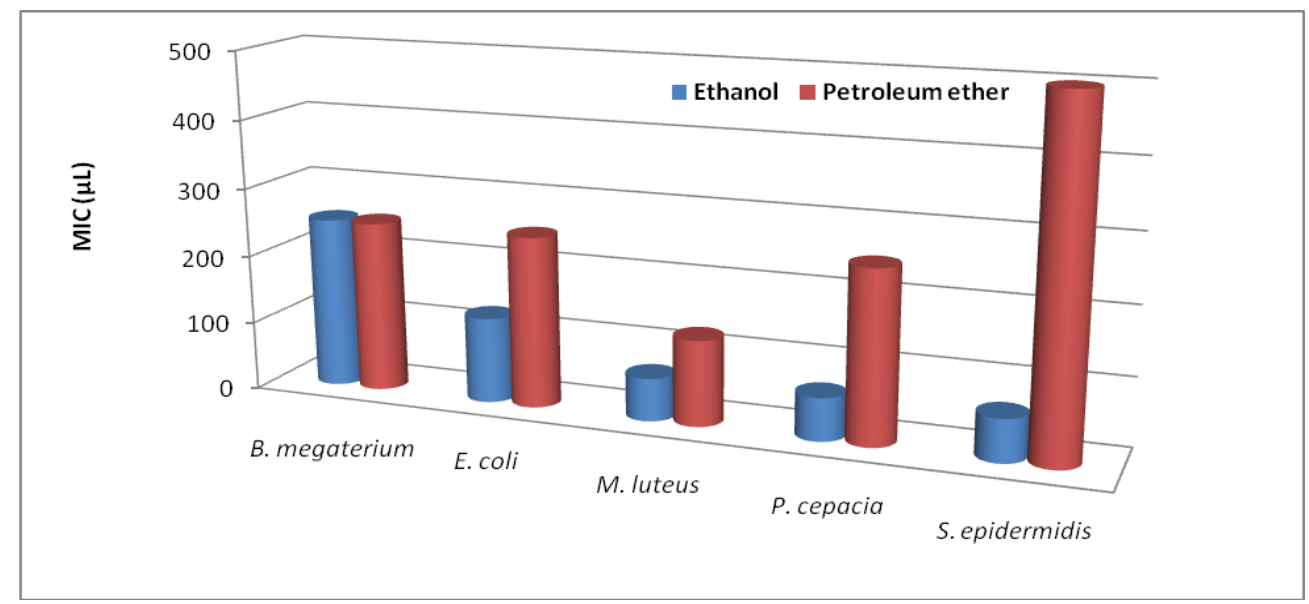

Fig. 3: Comparison of Minimum Inhibitory Concentration (MIC) of ethanolic and petroleum ether extracts of Tamilnadia uliginosa leaves.

The increasing the diseases and drug resistant strains of bacteria and fungi the bacterial strains are reduced susceptibility to antibiotic raises the presence of untreatable bacterial infections and adds necessity to the search for new drugs against resistant microorganisms (Janovska et al., 2003). Medicinal plants are vital source of chemotherapeutic agents. The phytochemicals are involved in the antibacterial activity and to assess the antibacterial assay is a first step towards this goal (Tona et al., 1998). Some of these observations have helped for identifying the active principle responsible for such activities and in the developing drugs for the therapeutic use in human beings. A study conducted by Karuppusamy et al. (2001a) showed that the phytomedicinal formulations used by the street herbal vendors in Tamil Nadu are having remarkably effective antimicrobial activity.

The results on the screening of different plant species collected from different parts of Tamil Nadu for antimicrobial activity showed encouraging results (Karuppusamy et al., 2001a and 2001b). The present study results are in accordance with the results obtained by Karuppusamy and Rajasekaran (2009). In the present study, antibacterial activity with least MIC was found in the extracts of Tamilnadia uliginosa in comparison with the extracts of Capparis sepiaria and Euphorbia heterophylla.

\section{Conclusion}

The preliminary phytochemical studies showed the presence of more number of phytoconstituents in ethanolic leaf extracts than in petroleum ether extracts. Antibacterial assay conducted using resazurin dye reduction test showed that the ethanol extracts of
Tamilnadia uliginosa leaves exhibited pronounced activity with low minimum inhibitory concentration $(62.5 \mu \mathrm{L})$ against the bacteria, Micrococcus luteus, Pseudomonas cepacia and Staphylococcus epidermidis. The observations in the present study shows that the extracts of Tamilnadia uliginosa leaves are possessing good antibacterial activity in comparison with other extracts tested in the study.

\section{Conflict of interest statement}

Authors declare that they have no conflict of interest.

\section{References}

Dahanukar, S.A., Kulkarni, R.A., Rege, N.N., 2000. Pharmacology of medicinal plants and natural products. Ind. J. Pharmacol. 32, S81-S118.

Gamble, J.S., Fischer, C.E.C., 1957. Flora of the Presidency of Madras (Vols. I-III). Authority of Secretary of State for India in Council, London. 1389p.

Harbone, J.B., 1973. Phytochemical Methods. Chapman and Hall Ltd, London. pp.49-188.

Janovska, D., Kubikova, K., Kokoska, L., 2003. Screening for Antimicrobial Activity of some medicinal plants species of traditional Chinese medicine. Czech J. Food Sci. 21(3), 107-110.

Karuppusamy, S., Rajasekaran, K.M., 2009. High throughput antibacterial screening of plant extracts by resazurin redox with special reference to medicinal plants of Western Ghats. Global J. Pharmacol. 3(2), 63-68.

Karuppusamy, S., Karmegam, N., Rajasekaran, K.M., 2001a. Antimicrobial screening of Asclepiadacean medicinal plants of Dindigul District, Tamil Nadu, South India. J. Ecotoxicol. Environ. Monit. 11, 47-51. 
Karuppusamy, S., Rajasekaran, K.M., Karmegam, N., 2001b. Evaluation of phytomedicines from street herbal vendors in Tamil Nadu, South India. Indian J. Trad. Knowl. 1, 26-39.

Matthews, K.M., 1983. The Flora of Tamil Nadu Carnatic. St. Joseph's College, Tiruchirappalli, Tamil Nadu, India. $1034 \mathrm{p}$.

Ogu, E.O., Agu, R.C., 1995. A comparison of some chemical properties of Garcina kola and Hops for assessment of garcinia brewing value. Bioresour. Technol. 54, 1-4.

Okwu, D.E., 2005. Phytochemicals and mineral contents of two Nigerian medicinal plants. Int. J. Mol. Med. Adv. Sci. 1(4), 375-381.

Prakash, M., Karmegam, N., 2012. In-vitro antibacterial activity of certain plant extracts against plant disease causing bacteria isolated from citrus plant. Int. J. Curr. Microbiol. App. Sci. 1(1), 1-11.

Sofowora, A., 1993. Medicinal plants and traditional medicine in Africa. Spectrum Books, Ibadan.

Trease, G.E., Evans, W.C., 1989. Trease and Evans' Pharmacognosy: A Physician's Guide to Herbal Medicine. 13th Edition, Bailliere Tindall London.

Tona, L., Kambu, K., Ngimbi, N., Cimanga, K., Vlietinck, A.J., 1998. Antiamoebic and phytochemical screening of some Congolese medicinal plants. J. Ethnopharmacol. 61, 57-65.

Vigneshwari, C., Nagaraj, R., Karmegam, N., 2014. Synergistic anti-Staphylococcus aureus (methicillin resistant) activity of ethnomedicinal plants from Shevaroy hills (Eastern Ghats), south India. Int. J. Curr. Res. Biosci. Plant Biol. 1(2), 51-59.

\section{How to cite this article:}

Kalpana, B., Prakash, M., 2017. Preliminary phytochemical analysis and antibacterial activity of leaf extracts of Capparis sepiaria, Euphorbia heterophylla and Tamilnadia uliginosa. Int. J. Curr. Res. Biosci. Plant Biol. 4(6), 114-120. doi: https://doi.org/10.20546/ijcrbp.2017.406.013 